\title{
Erratum to: Direct photo-patterning on anthracene containing polymer for guiding stem cell adhesion
}

Jungmok You', June Seok Heo ${ }^{2}$, Hyun Ok Kim²,3 and Eunkyoung Kim ${ }^{4 *}$

\section{Erratum}

n.b. The associated online manuscript has now been updated with this correction accordingly.

- The original version of the manuscript [1] displayed the lead author's name as "Eunkyoumg Kim", whereas it should have read "Eunkyoung Kim".

\begin{abstract}
Author details
'Department of Plant \& Environmental New Resources, Kyung Hee University, 1732 Deogyeong-daero, Giheung-gu, Yongin-si, Gyeonggi-do 446-701, South Korea. ${ }^{2}$ Cell Therapy Center, Severance Hospital, Yonsei University College of Medicine, Seoul, South Korea. ${ }^{3}$ Department of Laboratory Medicine, Yonsei University College of Medicine, Seoul, South Korea. ${ }^{4}$ Department of Chemical and Biomolecular Engineering, Yonsei University, 262 Seongsanno,

Seodaemun-gu, Seoul 120-749, South Korea.
\end{abstract}

Received: 8 August 2016 Accepted: 9 August 2016

Published online: 02 September 2016

\section{References}

1. You J, Heo JS, Kim HO, Kim E. Direct photo-patterning on anthracene containing polymer for guiding stem cell adhesion. Biomaterials Research. 2016;20:26. http://doi.org/10.1186/s40824-016-0072-4.

\footnotetext{
* Correspondence: eunkim@yonsei.ac.kr

${ }^{4}$ Department of Chemical and Biomolecular Engineering, Yonsei University, 262 Seongsanno, Seodaemun-gu, Seoul 120-749, South Korea

Full list of author information is available at the end of the article

Submit your next manuscript to BioMed Central and we will help you at every step:

- We accept pre-submission inquiries

- Our selector tool helps you to find the most relevant journal

- We provide round the clock customer support

- Convenient online submission

- Thorough peer review

- Inclusion in PubMed and all major indexing services

- Maximum visibility for your research

Submit your manuscript at www.biomedcentral.com/submit 